\title{
WEAPONISATION OF THE WAR ON TERROR AND THE SIDESTEPPING OF HUMAN RIGHTS NORMS: SEEKING A BALANCE BETWEEN THE TERRORISM (PREVENTION) (AMENDMENT) ACT 2013 AND NIGERIA'S OBLIGATION UNDER INTERNATIONAL HUMAN RIGHTS LAW
}

\section{Olusola Babatunde Adegbite ${ }^{1}$}

\begin{abstract}
$\mathrm{n}$ an era of escalation in terrorism and terrorist related criminalities, the international system continues to innovate on how best to contain its scourge, particularly within the confines of established democratic norms. As a response to Security Council resolution 1373 adopted on 28 September 2001, United Nations (UN) member states began to craft domestic counterterrorism legislations to criminalise terrorist activities on their home-soil, as well as extraterritorially. Responding as other nations, Nigeria enacted the Terrorism (Prevention) (Amendment) Act 2013. However, the Act and others like it, have thrown up troubling questions about weaponization of the war on terror, and the need to balance the war with the protection of human rights. This article examines the continued sidestepping of human rights norms in the war against terror. It presents this conflict within the context of Nigeria's domestic counterterrorism law, highlighting some dangerous provisions in the Act which directly impugns on its obligation under International Human Rights Law (IHRL). It advocates an urgent review in the Act that will reflect the current mood of the UN human rights system, as well as the country's obligation under IHRL.
\end{abstract}

Keywords: Nigeria, Domestic, Counterterrorism Law, Dignity, Personal Liberty, International Law

1 LL.B (Hons) (Ife), LL.M, (Ife), LL.M (Cardozo School of Law, Yeshiva University, New York), B.L., Lecturer, Department of Public Law, Faculty of Law, Obafemi Awolowo University, lle-Ife, NIGERIA. 
Weaponisation of the War on Terror and the Sidestepping of Human Rights Norms: Seeking a Balance between the Terrorism (Prevention) (Amendment) Act 2013 And Nigeria's Obligation under International Human Rights Law

\section{Introduction}

The making of a counterterrorism legislation in Nigeria, was a watershed moment in the deployment of legislation to address growing security challenges, fulfil a constitutional mandate, as well as meet an international commitment. Security wise, terrorism largely by Boko haram, a salafist fundamentalist groups had become rife, that it had considerably stretched the country's internal security architecture. ${ }^{2}$ Also, the government had a constitutional mandate under Section 14 (2) (b) of the constitution, which states that "the security and welfare of the people shall be the primary purpose of government". ${ }^{3}$ More so, as a member of the United Nations (UN), the country had a core responsibility to comply with an important UN decision i.e. UN Security Council resolution 1373 which had been adopted on 28 September 2001 as the immediate global response to the terrorist attacks of 11 September 112001 . The 2011 Act provided for the first time, a comprehensive domestic legal framework for counterterrorism in the country. The Act was subsequently amended following the passing into law, of the Terrorism (Prevention) (Amendment) Act 2013.

Like other legislations of its kith, the enactment and implementation of the Act have been confronted with issues bordering on human rights violations, putting both at loggerheads. Though there exist a general international consensus on the universality and inalienability of human rights, the question is whether governments such as Nigeria, were mindful of this in crafting their domestic counterterrorism legislation? Issues relate to how human rights norms have so far been applied in the country's effort at domestic counterterrorism, to ensure success in the war on terror? Do these two concepts share a symbiotic relationship in Nigeria, or is it case of two parallel lines that can never meet? Majorly, there has been a gap when it comes to understanding the importance of achieving a balance between the country's counterterrorism legislation and its obligation under International Human Rights Law (IHRL).

Against this backdrop, this article will be examining how the provisions of the TPA 2013 is at war with Nigeria's IHRL obligations, concerning the right to dignity and personal liberty. A key objective of the article is to highlight, through an examination of the progress already made under the UN human rights system, of how Nigeria still lags behind in terms of the need to balance counterterrorism and human rights. To achieve this, the article will be divided into eight (8) parts. While part I deals with the introduction, part II

2 O. Osumah, 'Boko Haram Insurgency in Northern Nigeria and the Vicious Cycle of Internal Security', (2013), 24 (3), Small War and Insurgencies, 536 - 560 at 550.

3 Constitution of the Federal Republic of Nigeria 1999 (Hereinafter '1999 Constitution'). 
will examine issues bordering on the tension between human rights and counterterrorism in contemporary times. Part III will explore the development of counterterrorism globally and how Nigeria had to comply with the prevailing international legal framework. Part IV will examine Nigeria's obligations under IHRL as it relates to the rights to dignity and personal liberty, while part $V$ will discuss how the provision of indefinite detention framework under the Act has resulted in a meltdown of the rights to dignity and personal liberty. Part VI will highlight developments under the UN human rights system pointing to a need to balance human rights and counterterrorism, and how this ought to inform a shift in Nigeria's counterterrorism law. Part VII discusses the important legislative step that Nigeria needs to take in this regard, while Part VIII covers the conclusion.

\section{Human Rights and Counterterrorism: A Symbiotic Relationship or Two Parallel Lines?}

\section{Human Rights: From then to Now}

Though human right is of a rich historical legacy, its current extraordinary presence is more of a contemporary event. From a protracted beginning that can be traced to the Magna carta, as well as the English bill of rights, ${ }^{4}$ the metamorphoses of human rights have been startlingly intricate. An irresistibly moving concept, that was initially viewed for centuries as a seemingly ordinary moral concept, human rights began to gain the much-needed attention with the dazzlingly powerful words in the American declaration of independence. ${ }^{5}$ This was followed by other important documents such as the American constitution, ${ }^{6}$ and French declaration of the rights of the man and the citizen. ${ }^{7}$ Despite the significance of these documents, human rights remained of astonishingly light-weight, for centuries. For instance, the world superpowers did not think much of human rights, when in extreme cruelty, they bludgeoned each other in both the first and second world wars. The horrors of these two wars, and the indignities that men, women, children, were subjected to, signaled a new consciousness, as it apparent that the world had had enough. This heralded a new era altering the human rights landscape dramatically. This became instructive given the understanding that threats to human rights is threat to global security, necessitating a responsibility to protect. ${ }^{8}$ Capturing this aptly, Makau 4 While the Magna carta was adopted on 15 June 1215, the English bill of rights got royal assent 16 Dec. 1689.

5 The Declaration was issued and adopted on 4 July, 1776.

6 This document was ratified on 21 June, 1788.

7 The Declaration was adopted on 26 August, 1789.

8 D.P. Forsythe, 'The United Nations and Human Rights: State Sovereignty and Human Rights', (2012,) International Policy Analysis, 1-13. 
Weaponisation of the War on Terror and the Sidestepping of Human Rights Norms: Seeking a Balance between the Terrorism (Prevention) (Amendment) Act 2013 And Nigeria's Obligation under International Human Rights Law

Mutua notes, "the post-world war II period has been characterized as the as the age of rights, an era during which the human rights movement has come of age". ${ }^{9}$

With the establishment of the UN and the adoption of its charter in $1945,{ }^{10}$ much of what now represents human rights emerged. Though what constitutes human right is still inherently complicated, following its establishment, the UN saw the need to give more bite to a framework of better safeguards, which led to the adoption of the Universal Declaration of Human Rights (UDHR) in 1948. ${ }^{11}$ The UDHR is the flagship document in the body of human rights instruments, ${ }^{12}$ and it considers human rights as the basis on which freedom, justice, and peace can be achieved. ${ }^{13}$ Through the Universal Declaration, human rights broke forth triumphantly from a undesirable history, to become the most significant discussion of the $20^{\text {th }}$ century. It acquired an allure that its early promoters could not have prospectively imagined. The Universal Declaration in its vociferous condemnation of man's inhumanity to man importantly notes that;

Disregard and contempt for human rights have resulted in barbarous acts which have outraged the conscience of mankind, and the advent of a world in which human beings shall enjoy freedom of speech and belief and freedom from fear and want has been proclaimed as the highest aspiration of the common people. ${ }^{14}$

It further provides direction by adding that;

It is essential, if man is not to be compelled to have recourse, as a last resort, to rebellion against tyranny and oppression, that human rights should be protected by the rule of law". ${ }^{15}$

9 M. Mutua, 'Hope and Despair for a New South Africa: The Limits of Rights Discourse', (1997), 10, Harvard Human Rights Journal, $63-114$ at 63.

10 Article 1 (3) of the UN Charter provides that, "to achieve international cooperation in solving international problems of an economic, social, cultural, or humanitarian character, and in promoting and encouraging respect for human rights and for fundamental freedoms for all without distinction as to race, sex, language or religion". See Charter of the United Nations (UN) signed in San Francisco California United States on 26 June, 1945.

11 This document is the foundation of $21^{1 \text { st }}$ century concept of human rights as well as IHRL. It was adopted following G. A. Res. 217 A (111), UN GAOR 3d Sess., UN Doc A/RES/217A (III) (10 Dec. 1948). 12 C.M. Serna, 'Universality of Human Rights and Cultural Diversity: Implementation of Human Rights in Different Socio-Cultural Contexts', (1994), 16, Human Rights Quarterly, 740 - 752 at 740.

13 D. Shelton, 'Challenges to the Future of Civil and Political Rights', (1998), 55, Washington and Lee Law Review, $669-680$ at 669,670 .

14 Preamble to the UDHR 1948.

15 UDHR 1948 (n. 14). 
The humble but gripping moment of the UDHR, led to emergence of other fiercer documents, notably amongst which are the International Covenant on Civil and Political Rights (ICCPR), ${ }^{16}$ the International Covenant of Social, Economic, and Cultural Rights (ICSECR),${ }^{17}$ the Convention Against Torture and Other Cruel, Inhuman, or Degrading Treatment or Punishment (CAT), ${ }^{18}$ Convention on the Elimination of All Forms of Discrimination Against Women (CEDAW), ${ }^{19}$ and the UN Convention on the Rights of the Child (CRC).$^{20}$ Through these instruments, human right has successfully run the gauntlet, to become the signpost of freedom in the modern state.

In the contemporary development of human rights, the right to dignity and personal liberty have been dominant themes. While human rights as a concept is founded on human dignity, the meaning and value of dignity has its roots in philosophical thoughts. Dignity views all human beings as equal in all normative respect and that no one should be prided as more equal than the other. It speaks of due recognition, respect, and fair treatment for all men. The idea that every man has inherent in him certain rights and privileges that are inalienable, constant, and proprietary in nature evolved from the understanding that, man as a superior being is an embodiment of values that makes him different from other works of creation, values that cannot be separated from his humanity. Dignity is therefore the source of both negative rights such as life, freedom from discrimination, fair hearing and freedom of movement, as well as positive rights such as education, health, and work. It is what institutes a system of rights. It is only on the basis of dignity that a man's life must not be taken arbitrarily, or his freedom curtailed without justification. Also, it is on the same ground that a man can claim to have his mind refined through education or have a means of livelihood through a decent work. Following the end of the second world war, the right to dignity became a major feature of majorly all national constitutions. ${ }^{21}$ One of the primary goals of the UN is to "to reaffirm faith in fundamental human rights, in the dignity and worth of the human person, in the equal rights of men and women and of nations large and small". ${ }^{22}$

16 UN Gen. Ass. Res. 2200 A (XXI) 16 Dec. 1966, (entered into force 23 Mar. 1976).

17 UN Gen. Ass. Res. 2200 A (XXI) 16 Dec. 1966, (entered into force 3 Jan. 1976).

18 UN Gen. Ass. Res. 39/46 10 Dec. 1984, (entered into force 26 June, 1987).

19 UN Gen. Ass. Res. 34/180 18 Dec. 1979, (entered into force 3 Sept. 1981).

20 UN Gen. Ass. Res. 44/25 20 Nov. 1989, (entered into force 2 Sept. 1990).

21 D. Shulztiner and G.E. Carmi, 'Human Dignity in National Constitutions: Functions, Promises, and Dangers', (2014), 62 (2), American Journal of Comparative Law, 461 - 490.

22 Preamble UN Charter 1945. 
Flowing from this sense of value, not only is man seen as a creation most precious, the full expression of his value can only be attained when he enjoys the right measure of liberty, to be what he was made to be. Based on this notion, the twin concepts of dignity and liberty have remained very strong pillars for the enthronement for human rights. Usually, where there is a violation of one, the other is most likely to be in view, or even happening simultaneously. Both rights are key component units of modern IHRL framework, and remain perhaps the most abused rights, after the right to life. Therefore, human rights in the real sense ought to be the promotion of dignity and liberty manifested in other rights. Right mindedness on dignity and liberty should be at the core of every security measure directly involving humans. That is how important dignity and liberty is to the war on terror, especially within the frame of that which any reasonable person would consider proper.

\section{Human Rights and Counterterrorism}

Any discussion on the contest between human rights and counterterrorism, is bound to evoke both poignancy and delirium. Poignancy, given the artificial wedge that has somewhat been brought between the two from the sudden burst of terrorism around the start of the new millennium. Delirium, based on the joy that a conversation on the two, may just be the beginning of some light at the end of the tunnel, towards achieving the long-canvassed cooperation between both concepts. The goal of the article is nestled in the need to find light at the end of this unnecessarily long tunnel, and a good place to start is where the problem in fact began. As brilliantly observed by Fitzpatrick, the human rights landscape essentially rests on the instrumentality of law and legal institutions, towards minimising the injury that the strong can do to the weak. ${ }^{23}$ However, recent events such as $9 / 11$ and the surge of counterterrorism that followed, has unearthed its inherent vulnerabilities. Notably, they have been on the offensive, pushing against the human rights architecture. ${ }^{24}$ As a matter of fact, the relentless assault has nearly flung the concept over the cliff.

Before counterterrorism assumed this front-row position, the human rights system could be said to have conceded so much, towards balancing human rights and the safeguard of state security, through its several controversial derogations.$^{25}$ Despite this, it appears the pro-counterterrorism group would not join the bandwagon of 'half bread is better

23 J. Fitzpatrick, 'Speaking Law to Power: The War Against Terrorism and Human Rights', (2003), 14 (2), European Journal of International Law, 241 - 264 at 242.

24 lbid.

$25 \mathrm{Ibid}$, at 243. 
than none'. Counterterrorism promoters, bypassing these derogations, continue to make incursions into the core texts of human rights provisions. It may be a counter-argument that under the same framework, human rights while restraining government's responses to terrorism, did little concerning terrorists. ${ }^{26}$ The horror of the $9 / 11$ attacks, the mindblowing devastations of plunging fully loaded passenger airlines into imposing office complexes, and the cold-blooded cum gruesome mass massacre of close to 3,000 innocent Americans, was a new watershed. ${ }^{27}$ This evil occurrence would appear to have done incalculable damage to any defence human rights may have been trying to mount all along. With the onslaught against terrorism post-9/11, leading nations such as the US began to crisscross the globe, searching for suspected terrorists and the need to bring them to book. The expectation was that such suspects, upon being apprehended would be put through a decent system of administration of transitional justice, encapsulated in a judicial process constituted solely to determine their guilt.28 The reality however has been far from this. In an era of detention camps and the explosion in state actions such as 'targeted killings', it can be said that the hostilities between human rights and counterterrorism may have come full circle.

At the forefront of the pro-counterterrorism coalition is the United States (US) who, as it has often been the case, regards its viewpoint as superior to that of any other nation. ${ }^{29}$ With its below par attitude towards human rights values, American policy makers in pursuit of counterterrorism objectives wade through the gaps in International Humanitarian Law $(\mathrm{IHL})$ and the law governing the use of force.$^{30}$ Despite this, stakeholders in the human right system have not failed to keep up the push-back, maintaining their position that further destruction of human rights values, will only help terrorist overcome basic principles such as human dignity and rule of law. ${ }^{31}$ Though the needless issues between human rights and counterterrorism has greatly overshadowed the huge legislative milestone recorded following the enactment of the TPA 2013, the matter did not start in Nigeria. Nigeria's counterterrorism law is simply a part of the giant $21^{\text {st }}$ century international law jigsaw on counterterrorism. It is important to examine the how this jigsaw came to be, to put in context how Nigeria arrived at this point.

26 Ibid.

$27 \mathrm{lbid}$, at 243, 244.

28 O.B. Adegbite, 'The Cloak the Turban and Slippery Slopes: The Cleric as a Direct Participant in Hostilities and the Right to Protected Status under International Humanitarian Law', (2018), 26 (1), Lesotho Law Journal, 79 - 104 at 103, 104.

29 J. Fitzpatrick, supra, n.22, 245.

30 Ibid.

31 Ibid. 
Weaponisation of the War on Terror and the Sidestepping of Human Rights Norms: Seeking a Balance between the Terrorism (Prevention) (Amendment) Act 2013 And Nigeria's Obligation under International Human Rights Law

\section{Counterterrorism under $21^{\text {st }}$ UN Human Rights System: Nigeria in Perspective}

Earlier, terrorism was viewed as a matter relating to international criminal conduct, and so international criminal law treaties obliged governments to criminalise terrorism related acts, while also cooperating with other governments towards punishing suspected terrorists. ${ }^{32}$ The dastardly events of 11 September 2001 (hereinafter '9/11') however significantly altered the landscape. Reported to have been perpetrated by nineteen members of the outlawed AI Qaeda terrorist network, 9/11 saw two American passenger planes plunge into the twin towers of the world trade centre in New York City, while two other planes targeted the US military headquarters in Pentagon, as well as an area in Pennsylvania. ${ }^{33}$ These events nearly brought the whole world to a standstill, with emotions reaching fever pitch, what is however relevant for the purpose of this article, is the legal developments that later followed.

A significant development in this respect is the leadership demonstrated by the UN. On 28 September 2001 the United Nations Security Council (UNSC), pursuant to its powers under Chapter VII of the UN charter, adopted resolution 1373, which was expected to be binding on member states. ${ }^{34}$ The resolution, which put in place a fitting framework for counterterrorism, mandated member states to provide for the crime of terrorism in their domestic laws, cooperate towards combatting terrorist financing, share intelligence, and implement international treaties bordering on terrorism. ${ }^{35}$ States were also to ensure that they do not accommodate asylum seekers known to have been involved in terrorist activities. ${ }^{36}$ The resolution also established a fifteen-member antiterror body called the UN Counterterrorism Committee (CTC), which required member states to submit reports on steps taken towards carrying out the intentions of the resolution, within ninety days of the resolution, and periodically afterwards. ${ }^{37}$ In 2004 the UNSC adopted resolution 1540

32 S.P. Marks, 'International Law and the 'War on Terrorism': Post 9/11 Responses by the United States and Asia Pacific Countries', (2006), 14 (1), Asia Pacific Law Review, 48.

33 C. Marken, Counterterrorism and the Detention of Suspected Terrorists: Preventive Detention and International Human Rights Law, (Milton Park, Abingdon, Oxon: Routledge Publishers, 2011), 1 - 98 at 1; S. Boyne, 'Law, Terrorism, and Social Movement: The Tension Between Politics and Security in Germany's Anti-Terrorism Legislation', (2004), 12 (1), Cardozo Journal of International and Comparative Law, 41 - 82 at 75,76 .

34 J. Santana, 'In the Aftermath of Resolution 1373: Tackling the Protective Veil of Counterterrorism', (2015), 23 (3), Cardozo Journal of International and Comparative Law, 663 - 693 at 676.

35 S.B. Adarkwah, 'Counterterrorism Framework and Individual Liberties in Ghana', (2020), 28 (1), African Journal of International and Comparative Law, 50 - 65 at 50.

36 S.P. Marks, supra, n. 31, 49.

37 C. Marken, supra, n. 32; J. Santana, supra, n. 33, 676; W.S. Heinz and J. Arend, The International 
in which states are prohibited from providing support to non-state actors attempting to procure biological, chemical, and nuclear weapons. ${ }^{38}$ Resolution 1373 practically gave powers to national governments to go after terrorists within the nooks and crannies of their space ${ }^{39}$ Creating a major lacuna, the resolution made no mention of the need for member states to respect their international human rights obligations. ${ }^{40}$ Following 9/11, there was an avalanche of legislations enacted to protect citizens against acts of terror by persons and groups ${ }^{41}$ In the sweltering and panic mode of this era, governments obviously reeling under the pressure of the resolution, began to enact rather draconian domestic counterterrorism legislations.

Nigeria's reaction to the resolution was not different from that of most UN member states. In 2011, it enacted the Terrorism (Prevention) Act. ${ }^{42}$ The Act was later supplanted by the Terrorism (Prevention) (Amendment) Act 2013 (Hereinafter the 'Act'), which is currently the country's principal counterterrorism legislation. ${ }^{43}$ Before the 2011 move, Nigeria's counterterrorism framework was practically blurry, notwithstanding that the country had earlier recorded incidences that had the signature of terrorism. The country did not have a direct legislation on terrorism, and related acts were simply brought under the Criminal Code Act, ${ }^{44}$ the Penal Code Act, ${ }^{45}$ and the Economic and Financial Crimes Commission (Establishment) Act 2004 which defined terrorism and accordingly provided for sanctions. ${ }^{46}$

Fight Against Terrorism and the Protection of Human Rights, (Berlin: German Institute for Human Rights, 2005), 1 - 43 at 11; HRW, 'In the Name of Counterterrorism: Human Rights Abuses Worldwide', (March 25, 2003), A Human Rights Watch Briefing Paper for the $59^{\text {th }}$ Session of the United Nations Commission on Human Rights (UNCHR), $1-25$ at 4.

38 C. Lumina, 'Counter-Terrorism Legislation and the Protection of Human Rights: A Survey of Selected International Practice', (2007), 7 (1), African Human Rights Law Journal, 35 - 67 at 40.

39 S.B. Adarkwah, supra, n. 34, 51.

40 HRW, supra, n. 36, 4.

41 A. Shepherd, 'Extremism, Free Speech, and the Rule of Law: Evaluating the Compliance of Legislation Restricting Extremist Expressions with Article 19 ICCPR', (2017), 33 (85), Utrecht Journal of International and European Law, $62-83$ at 62.

42 Terrorism (Prevention) Act No. 102011.

43 Terrorism (Prevention) (Amendment) Act 2013. The Explanatory Memorandum of the Act states that, "This Act amends the Terrorism Prevention Act No. 102011 makes provision for extra-territorial application of the Act and strengthen terrorist financing offences".

44 CAP 38, Laws of the Federation of Nigeria, (LFN) 2004.

45 CAP 89, Laws of the Federation of Nigeria, (LFN).

46 C.E. Attah, 'Boko Haram and Sexual Terrorism: The Conspiracy of Silence of Nigeria's Anti-Terrorism Laws', (2016), 16 (2), Africa Human Rights Law Journal, 385 - 406 at 397. 
Despite the generally acclaimed importance of the Act as the vehicle of counterterrorism in the country, a major challenge lies in its contempt for established human rights norms. The provisions of the Act have portrayed it as a legislation, either totally unmindful of the place of Nigeria's human rights obligations under IHRL, or though abreast of these obligations, is really unperturbed as too how much Nigeria complies. For instance, since the enactment of the Act, its implementation has been fraught with issues, particularly as regards how some of its provisions undermines established human rights norms, and carpets Nigeria's obligation under IHRL. Since its operationalization, there have been reported cases of politically exposed persons, simply arrested for making pronouncements that the government frowns at, only for them to be charged with terrorism and other crimes. Not only are these persons arrested, they are sometimes detained indefinitely, without any effort to bring them before a court for the determination of the charges against them. In some instance, even after they are charged and upon successful arraignment, they are immediately re-arrested on new charges, giving an impression that the initial arraignment was just a phony move to douse public pressure.

The gestapo implementation of the Act has particularly impacted on the right to dignity and personal liberty. Through the action of its agents in implementing the Act, Nigeria as a state party to several IHRL instruments, has failed to comply with its treaty obligations on these two rights, which imperils its standing in the international community. As this article will later demonstrate, the Nigerian government via its extreme provisions under the country's counterterrorism legislation, has significantly dropped the ball in terms of its IHRL obligations, an attitudinal disposition extremely dangerous for the overall sustenance of democratic values and the rule of law. To understand how the Act has been antagonistic to these two rights, it is important to proceed to examine what Nigeria's obligations in this regard are, under IHRL.

\section{Right to Dignity and Personal Liberty: What is Nigeria's Obligation under International Human Rights Law?}

\section{IHRL: Nigeria's Obligations}

To lay a demand on a State to protect human rights, is to proceed from the standpoint that the State has such responsibility to start with. Such proposition cannot be whimsical, but must be a product of relevant laws, crafted in clear terms. Such are the nature of IHRL treaties that States such as Nigeria are signatories to. Human rights treaties generally establish an objective framework for the protection of rights and fundamental freedoms. ${ }^{47}$ 47 K. Korkelia, 'New Challenges to the Regime of Reservations under the International Covenant on Civil 
They also create obligations between states as well as individuals, who are deemed the direct beneficiaries. ${ }^{48}$ Since independence, Nigeria has been a signatory to the UN charter and other binding IHRL treaties dealing with the protection of dignity and personal liberty. The UDHR takes human dignity very seriously and in its openings statement, it states that, "recognition of the inherent dignity and of the equal and inalienable rights of all members of the human family is the foundation of freedom, justice, and peace in the world" ${ }^{49}$ It then proceeds to situate correctly the obligation of each member nation by stating that;

The peoples of the United Nations have in the Charter reaffirmed their faith in fundamental human rights, in the dignity and worth of the human person, and in the equal rights of men and women, and have determined to promote social progress and better standards of life in larger freedom. ${ }^{50}$

On the protection of this right, there is an expectation on all signatories to uphold and implement provisions of the UDHR and other relevant treaties. Nigeria for instance is expected to uphold Article 1 which provides that, "all human beings are born free and equal in dignity and rights. They are endowed with reason and conscience and should act towards one another in a spirit of brotherhood". ${ }^{51}$ Aside the UDHR, Nigeria is a signatory to other relevant instruments such as the ICCPR and CAT, both already mentioned above. At the regional level, it is also a signatory to the African Charter on Human and Peoples' Rights (ACHPR). ${ }^{52}$

Right to Dignity of the Human Person

Interestingly, more than 50 years before the Act was even imagined, the kinds of inhumane behaviour that has since been associated with its implementation was already envisaged by the committee of nations through Article 5 of the UDHR which states that, "No one shall be subjected to torture or to cruel, inhuman or degrading treatment or

and Political Rights', (2002), 13 (2), European Journal of International Law, 437 - 477 at 439.

48 lbid.

49 Preamble to the UDHR,1948.

50 UDHR, 1948.

51 UDHR 1948.

52 African Charter on Human and Peoples' Rights (ACHPR), adopted 27 June, 1981 OAU Doc. CAB/ LEG/67/3 rev. 5, 21 I.L.M. 58 (1982) (entered into force 21 October, 1986); E. Babatunde, 'Torture by the Nigerian Police Force: International Obligations, National Responses and the Way Forward', (2017), 2 (1), Strathmore Law Review, 169 - 187 at 169. 
Weaponisation of the War on Terror and the Sidestepping of Human Rights Norms: Seeking a Balance between the Terrorism (Prevention) (Amendment) Act 2013 And Nigeria's Obligation under International Human Rights Law

punishment" ${ }^{33}$ This provision was later affirmed in Article 7 of the ICCPR, providing that;

No one shall be subjected to torture or to cruel, inhuman or degrading treatment or punishment. In particular, no one shall be subjected without his free consent to medical or scientific experimentation. ${ }^{54}$

Generally, it is agreed that "cruel, degrading, and inhuman treatment", is a direct attack on the dignity of a person. However, though the influence of the UDHR in advancing the idea of dignity has been quite impressive over the years, given that it is merely a declaration, it really has not been the right authority, to bindingly compel nations to behave properly. Instruments that imposes more binding authority on Nigeria are the ICCPR and the ACHPR. Article 7 of the ICCPR prohibits torture, cruel, inhuman or degrading treatment of punishment. ${ }^{55}$ The same right is captured under Article 5 of the ACHPR which provides that;

Every individual shall have the right to the dignity inherent in a human being and to the recognition of his legal status. All forms of exploitation and degrading of man particularly slavery slave trade, torture, cruel, inhuman and degrading punishment and treatment shall be prohibited. ${ }^{56}$

This provision was given voice in Commission Nationale Des Droits De l'Homme et des Libertes v. Chad, ${ }^{57}$ where the commission held that that the failure of the Chadian government to protect its citizen from torture was a violation of Article $5 .{ }^{58}$

When it comes to the international legal regime safeguarding 'dignity', the UN Convention Against Torture and Other Cruel, Inhuman, or Degrading Treatment or Punishment (Hereinafter the 'CAT'), ${ }^{59}$ is the principal instrument. This instrument upholds the provisions of both the UDHR and ICCPR. It calls the attention of the human community, to the earlier commitment of the international community in the UN Declaration on the Protection of All Persons from Being Subjected to Torture and Other Cruel, Inhuman or

\section{UDHR 1948.}

54 International Covenant on Civil and Political Rights (ICCPR), 9 Dec. 1966, 999, U.N.T.S. 171, (entered into force 23 Mar. 1976).

55 ICCPR 1966.

56 ACHPR 1981.

57 Commission Nationale Des Droits De l'Homme et des Libertes v. Chad, AfrComm HPR, Comm No. 74/1992, Activity Report (1995), quoted in E Babatunde, supra, n. 51, 181.

58 E. Babatunde, supra, n. 51, 181.

5910 Dec. 1984, 23 I.L.M. 1027. 
Degrading Treatment or Punishment. ${ }^{60}$ In order that every person may be clear on what would amount to torture, Article 1 of the CAT provides a well-rounded definition which states that;

For the purposes of this Convention, the term 'torture' means any act by which severe pain or suffering, whether physical or mental, is intentionally inflicted on a person for such purposes as obtaining from him or a third person information or a confession, punishing him for an act he or a third person has committed or is suspected of having committed, or intimidating or coercing him or a third person, or for any reason based on discrimination of any kind, when such pain or suffering is inflicted by or at the instigation of or with the consent or acquiescence of a public official or other person acting in an official capacity. It does not include pain or suffering arising only from, inherent in or incidental to lawful sanctions. ${ }^{61}$

Making the point that the prohibition on torture flows from the UN's understanding that "those rights derive from the inherent dignity of the human person", ${ }^{2}$ and the need "to make more effective the struggle against torture and other cruel, inhuman or degrading treatment or punishment throughout the world", ${ }^{63}$ the CAT lays down ground rules to prohibit torture in every part of the world. Article 2, for instance states that;

Each State Party shall take effective legislative, administrative, judicial or other measures to prevent acts of torture in any territory under its jurisdiction. No exceptional circumstances whatsoever, whether a state of war or a threat of war, internal political instability or any other public emergency, may be invoked as a justification of torture. An order from a superior officer or a public authority may not be invoked as a justification of torture. ${ }^{64}$

Article 4 (1) \& (2) further adds that, "each state party shall ensure that all acts of torture are offences under its criminal law. The same shall apply to an attempt to commit torture and to an act by any person which constitutes complicity or participation in torture. Each State Party shall make these offences punishable by appropriate penalties which take into account their grave nature". ${ }^{55}$ Article 5 of the CAT enjoins state parties to thoroughly 60 Adopted by the UN General Assembly 9 Dec. 1975.

61 UN Convention Against Torture and Other Cruel, Inhuman, or Degrading Treatment or Punishment (CAT), Gen. Ass. Res. 39/46, 10 Dec. 1984, (entered into force 26 June 1987).

62 Preamble to the CAT 1984.

63 Preamble to CAT 1984.

64 CAT 1984.

$65 \mathrm{lbid}$. 
investigate all cases of torture in its immediate domain, ${ }^{66}$ or any of its territories as provided in Article $12 .{ }^{67}$ Article 6 and 7 provides that where a case has been established concerning such investigation, criminal prosecution should be commenced against such accused persons, ${ }^{68}$ and Article 8 provides for extradition, where such is appropriate in the instant case. ${ }^{69}$ In the course of prosecuting such a person so extradited, Article 9 of the Convention admonishes States to cooperate in terms of sharing of information and evidence, that would ensure conviction. ${ }^{70}$

For victims of torture, Article 14 imposes a duty on State parties to ensure that victims are able to access redress and adequate compensation, and where a victim has unfortunately passed away by reason of the torture, the dependents must be compensated for their loss. ${ }^{71}$ Article 15 renders invalid any confession that may have been extracted by subjecting persons to acts of torture, ${ }^{72}$ a position that is consistent with established principles of the law regarding evidence. In addition to these established IHRL obligations, further safeguards of these rights have been constitutionalized in Nigeria. ${ }^{73}$ For example, Section 34 of the Constitution provides that, "every individual is entitled to respect to dignity of his person; accordingly, no person shall be subject to torture or to inhuman or degrading treatment..." ${ }^{74}$ The above provision has a corollary in Section 17 which states that, "in furtherance of the social order, the sanctity of the human person shall be recognized and human dignity shall be maintained and enhanced". ${ }^{75}$ It is clear that both the Nigerian Constitutional framework and IHRL obligations through the CAT, considers torture not only as a violation of the right to human dignity, but indeed a grave one.

66 Ibid.

67 Ibid.

$68 \mathrm{lbid}$.

69 Ibid.

70 lbid.

71 lbid.

72 Ibid.

731999 Constitution.

74 lbid,

75 lbid. 


\section{Right to Personal Liberty}

Regarding, the right to personal liberty, Article 3 of the UDHR provides that, "Everyone has the right to life, liberty, and the security of person", ${ }^{76}$ while Article 9 also states that, "no one shall be subjected to arbitrary arrest, detention, or exile". ${ }^{77}$ Giving support to the UDHR, Article 9 of the ICCPR provides in an extensive form how personal liberty should be guarded;

Everyone has the right to liberty and security of person. No one shall be subjected to arbitrary arrest or detention. No one shall be deprived of his liberty except on such grounds and in accordance with such procedure as are established by law. Anyone who is arrested shall be informed, at the time of arrest, of the reasons for his arrest and shall be promptly informed of any charges against him. Anyone arrested or detained on a criminal charge shall be brought promptly before a judge or other officer authorized by law to exercise judicial power and shall be entitled to trial within a reasonable time or to release. It shall not be the general rule that persons awaiting trial shall be detained in custody, but release may be subject to guarantees to appear for trial, at any other stage of the judicial proceedings, and, should occasion arise, for execution of the judgement. Anyone who is deprived of his liberty by arrest or detention shall be entitled to take proceedings before a court, in order that that court may decide without delay on the lawfulness of his detention and order his release if the detention is not lawful. Anyone who has been the victim of unlawful arrest or detention shall have an enforceable right to compensation. ${ }^{78}$

In safeguarding the right to personal liberty, the ACHPR provides in Article 6 that;

Every individual shall have the right the liberty and to the security of his person. No one may be deprived of his freedom except for reasons and conditions previously laid down by law. In particular, no one may be arbitrarily arrested or detained. ${ }^{79}$

The clause, 'In particular, no one may be arbitrarily arrested or detained', is very instructive in the context of counterterrorism legislations which often seek to detain suspects without restraints. Additionally, under the Nigerian Constitution Section 35 states that;

76 Article 3, UDHR 1948.

77 Article 9, UDHR 1948.

78 Article 9, ICCPR 1966.

79 ACHPR 1981. 
Weaponisation of the War on Terror and the Sidestepping of Human Rights Norms: Seeking a Balance between the Terrorism (Prevention) (Amendment) Act 2013 And Nigeria's Obligation under International Human Rights Law

Every person shall be entitled to his personal liberty and no person shall be deprived of such liberty save in the following cases and in accordance with a procedure permitted by law... ${ }^{80}$

Nigeria ratified the ICCPR on 29 July 1993, the CAT on 28 June 2001, and the ACHPR on 22 June $1983 .{ }^{81}$ This makes all the above provisions binding on Nigeria, to the end that successive governments are expected to respect the country's international obligations in this regard. In terms of legal standing, the ACHPR may be said to edge out both the ICCPR and the CAT, in the sense that it has been domesticated in Nigeria, and thus has the force of law. ${ }^{82}$ Necessarily, and by the decision of the supreme court in Abacha $v$. Fawehinmi, ${ }^{83}$ this means that it has the same standing as any validly made Act of the national assembly. ${ }^{84}$ One can also add, that by implication, it ought to instruct lawmaking bodies at all levels of government as regards Nigeria's obligation under the ACHPR, and the important need to be guided by this obligation in crafting the any law. Such mindedness ought to have trailed the enactment and eventual implementation of the Act, however Nigeria's obedience in this respect, as would be seen in the next part of this article, leaves so much to desire.

\section{The Meltdown of the Rights to Dignity and Personal Liberty under the Terrorism (Prevention) (Amendment) Act 2013: Analysing the Indefinite Detention Framework.}

Acts of terror are generally regarded as violations of human rights, with rights such as life, physical integrity, security, etc. often greatly impacted. ${ }^{85}$ What however appears stark is that with counterterrorism management comes terror-stricken legislations which also violates human rights. Notwithstanding their centrality to the war against terror, domestic counterterrorism legislations have become perhaps the biggest threat to human rights with in terms of offences, detention powers, proscription of terrorist organisations, as well as curtailment and investigative powers ${ }^{86}$ Thus, the evil that counterterrorism legislations seek to combat end up being the same it creates. Nigeria's counterterrorism legislation is

801999 Constitution.

81 E. Babatunde, supra, n. 51, 169.

82 African Charter on Human and Peoples' Rights (Ratification and Enforcement), Act CAP 10 Laws of Federation of Nigeria, (LFN) 1990. E. Babatunde, supra, n. 51, 181.

83 (2000) 6 NWLR (part 660).

84 Section 12, 1999 Constitution.

85 C. Lumina, supra, n. $37,59$.

86 O.A. Arebamen, P.E. Oamen, and B. Abegunde, 'The Impact of Counter-Terrorism Laws on the Protection of Human Rights and Fundamental Freedoms', (2015), 3 (1), Akungba Law Journal, 131 - 149 at 138 . 
an example in this regard. This article takes the view that the Act represents an arbitrary violation of the right to dignity and personal liberty, two rights globally recognized as significant to the overall humanity of any individual. The two rights are caught in the vortex of the 'indefinite detention framework' provided under the Act.

Certain deleterious provisions of the Act, having the appearance of 'absoluteness', have been perfect excuse for human rights violations by agents of the state. Analysis of these dangerous provisions is imperative at this point. To start with, section $27(1),{ }^{87}$ provides that;

The court, may pursuant to an ex parte application grant an order for the detention of a suspect under this Act for a period not exceeding 90 days, subject to renewal for a similar period until the conclusion of the investigation and prosecution of the matter that led to arrest and detention is dispensed with. ${ }^{88}$

Section 28 (4) further adds that;

Where a person arrested under this Act is granted bail by a court within the 90 days detention period stipulated by this Act, the person may, on the approval of the Head of the relevant law enforcement agency be placed under a House arrest shall (a) be monitored by its officers; (b) have no access to phones or communication gadgets; and (c) speak only to his counsel until the conclusion of the investigation. ${ }^{89}$

Section 27 (1) and 28 (4) of the Act reflects what can be described as 'preventive detention of suspected terrorists'. ${ }^{90}$ This was one of the controversial measures that emerged in post-9/11 counterterrorism legislation making, which allowed the governments to detain suspected terrorists without criminal trial, pending the conclusion of investigation. ${ }^{91}$ In countries such as Brazil, Colombia, France, Germany, Greece, Norway, Spain, and Turkey, there is a pre-trial detention framework. ${ }^{92}$ On the one hand, the detention is meant to allow security agencies obtain evidence towards prosecution, while on the other hand it helps to disrupt the network of the terrorists. ${ }^{93}$

87 Terrorism (Prevention) (Amendment) Act 2013.

$88 \mathrm{lbid}$.

89 lbid.

90 C. Marken, supra, n. 32, 2.

$91 \mathrm{lbid}$.

92 Ibid.

93 Ibid. 
Ordinarily, preventive detention is expected to strengthen counterterrorism effort and ensure that government not only gain valuable evidence to prosecute terror suspects, but also effectively truncate the chain of acts of terror that may still be in process. However, under the Nigeria's counterterrorism law, this supposedly effective tool has been taken to the extreme, with the Act's seemingly indefinite detention framework. For one, the wording of sections 27 (1) and 28 (4) are so wide and absolute, that it appears to grant unlimited powers to relevant law enforcement agencies to detain anyone alleged of terrorist act indefinitely. A particularly worrisome clause is that in section 27 (1) which says;

The detention of a suspect under this Act for a period not exceeding 90 days subject to renewal for a similar period until the conclusion the investigation and prosecution of the matter. $^{94}$

There is a suspicion that the drafters of the Act may have felt at ease when constructing this provision given the unsavoury safety net that would appear to have been provided in the constitution. Section 35 (1) of the Constitution, in providing an exception to the right to personal liberty states that;

Every person shall be entitled to his personal liberty, and nobody shall be deprived of such liberty save in the following cases and in accordance with a procedure permitted by law... provided that a person who is charged with an offence and who has been detained in lawful custody awaiting trial shall not continue to be kept in such detention for a period longer than the maximum period of imprisonment prescribed for the offence..$^{95}$

The implication of this constitutional provision is that where the DSS arrests anyone suspected under certain provisions of the Act, in addition of section 27 (1) of the Act above, the agency is permitted to continue to hold the suspect as long as the period of detention does not exceed the stipulated period of imprisonment under the Act. This means that where for instance the Act prescribes 10years imprisonment for an offence, anyone arrested in relation to such offence can be detained without trial for up to ten years. However, it would appear that the right to personal liberty still enjoys some safeguard under the constitution. In this respect, section 35 (4) (b) states that;

Any person who is arrested or detained in accordance with subsection 1 (c) of this section shall be brought before a court of law within a reasonable time and if he is not

94 Terrorism (Prevention) (Amendment) Act 2013.

951999 Constitution. 
tried within a period of three months from the date of his arrest or detention in the case of a person who has been released on bail, he shall (without prejudice to any further proceedings that may be brought against him) be released either unconditionally or upon such conditions as are reasonably necessary to ensure that he appears for a trial at a later date. ${ }^{96}$

This provision of the constitution provides that the maximum time any person can be detained for any offence is for a period of three months, and nothing more. At the end of the three months such a person is expected to be released unconditionally where no trial is brough against him/her, or released upon conditions that would enable trial be commenced against such at a later date. The Constitution neither recognizes nor permit a renewal of the three months period of detention as slated in section 27 (1) of the Act. It is clear that introduction of this provision in the Act by the drafters is geared towards undermining an important part of the Constitution that safeguards fundamental rights. The Constitution in section 35 (5) has also defined 'reasonable time' to mean any of the following "in the case of an arrest or detention in any place where there is a court of competent jurisdiction within a radius of 40 kilometres, a period of one day", or "in any other case, a period of two days.... ${ }^{77}$ The court may also determine what reasonable time means. Therefore, the drafters of the Act cannot hide behind the vagueness of 'reasonable time' as the basis for indefinite detention under section 27 (1) of the Act. However, harmony between the Section 27 of the Act and section 35 of the Constitution, appears to have been achieved in the provision of Section 35 (7) (a) which provides that;

Nothing in this section shall be construed in relation to subsection (4) of this section, as applying in the case of a person arrested or detained upon reasonable suspicion of having committed a capital offence. ${ }^{98}$

For the most part, insufficient attention has been paid to this part of the constitutions which seeks to aid and abet the Act. Worryingly, these provisions are not only anachronistic and draconian, they are totally inconsistent with established human rights norms accepted globally a well as Nigeria's obligation under IHRL, as regards respect for the right of personal liberty. Also, the fact that section 28 (4) attempts to provide a route for government to qualify a bail validly granted the defendant by a competent court of jurisdiction, leaves so much to be desired. It is important to make the point that provisions of section 28 (4) appear to have been cleverly inserted in the Act, to oust the 96 Ibid.

$97 \quad$ Ibid.

98 Ibid. 
powers of the court. Yet, section 6 (b) of the Nigerian Constitution provides that;

The judicial powers vested in accordance with the foregoing provisions of this section - shall extend to all matters between persons, or between government or authority and to any persons in Nigeria, and to all actions and proceedings relating thereto, for the determination of any question as to the civil rights and obligations of that person. ${ }^{99}$

The phrase 'determination of any question as to the civil rights and obligations' referred to here concerns the right to personal liberty provided for under section 35 of the Constitution. ${ }^{100}$ The same right is protected by Article 9 of the UDHR which states that "no one shall be subjected to arbitrary arrest, detention, and exile". A similar provision is also found in Article 9 of the ICCPR which provides that;

Everyone has a right to liberty and security of his person. No one shall be subjected to arbitrary arrest and detention. No one shall be deprived of his liberty except on such grounds and in accordance with such procedure as are established by law. ${ }^{101}$

The key phrase here is 'arbitrary arrest and detention'. It is clear that not only are section 27 (1) and 28 (4) of the Act retrogressive, both violates the Constitution, as well as relevant provisions under IHRL. Both provisions also represent a clear and present danger to whole idea of rule of law, as they espouse the smuggling of arbitrary exercise of powers into an otherwise important counter-terrorism legislation. It is inconceivable that the law will permit such impunity.

It may be made an argument that the 'indefinite detention framework' is required given a sort of 'state of emergency' that terrorism imposes, and the need to apply all measures necessary to protect national security. Though a convenient argument, yet it still falls short of the prescribed standards. Nigeria's obligations under IHRL does not permit this sort of defence, which comes under permitted derogations. The provision of derogations is a part of IHRL, except that it is only allowed in certain instances. As regards the right to human dignity and personal liberty, IHRL is clear on what is allowed and what is prohibited. The ICCPR perhaps having countries like Nigeria in mind, affirms this point, stating that;

In time of public emergency which threatens the life of the nation and the existence of which is officially proclaimed, the States Parties to the present Covenant may take 99 lbid.

$100 \mathrm{lbid}$.

101 ICCPR 1966. 
measures derogating from their obligations under the present Covenant to the extent strictly required by the exigencies of the situation, provided that such measures are not inconsistent with their other obligations under international law and do not involve discrimination solely on the ground of race, colour, sex, language, religion or social origin. No derogation from articles 6, 7, 8 (paragraphs 1 and 2), 11, 15, 16 and 18 may be made under this provision.... ${ }^{102}$

It is clear therefore that both right to dignity and personal liberty are non-derogable rights. It is not an exculpatory ground that the provisions analysed above i.e. sections 27 (1) and 28 (4) of the Act, are meant to ensure national security. Indeed, national security ought to proceed from the protection of the people and their rights, and not the other way round.

\section{Balancing Human Rights and Counterterrorism: Developments in the Post-UNSC Resolution 1373 era and Lessons for Nigeria.}

A major objective of constitutional democracies, is to safeguard their people against the scourge of terrorism while correspondingly upholding human rights and the rule of law. ${ }^{103}$ This is however no easy matter, given that persons suspected of terrorism and undergoing trial, are also expected to be able to enjoy their rights pending conviction. So how is this pot of rights to be adequately stirred, and yet not crash into the fire? The place to start, is the understanding that human rights are today recognized as intrinsically important when it comes to domestic counterterrorism legislative measures. Describe as a 'war without rules', ${ }^{104}$ it cannot be that counterterrorism will be carried out, without limitations particularly those imposed by human rights norms. The early quarrels between counterterrorism and human rights were made possible by the UNSC which did not consider human rights violations by countries, or try to determine how UNSC Resolution 1373 would affect the protection of human rights. ${ }^{105}$ This deprived the international community of a uniform framework, and allowed the implementation of the resolution to differ from country to country, in areas such as definition of terrorism as well as counterterrorism approach and system. ${ }^{106}$

102 Article 4 (1) (2) \& (3), ICCPR 1966.

103 N. Mavronicola, 'Protecting Human Rights while Countering Terrorism: The Role of National Human Rights Institutions', (2016), Brainstorming Meeting organised by Office of the Council of Europe Commissioner for Human Rights and the European Network of National Human Rights Institutions, 1 - 16 at 5.

104 J. Fitzpatrick, supra, n. 22, 248.

105 J. Santana, supra, n. 33, 676.

106 Ibid, at 676, 677. 
The sidestepping of IHRL obligations by resolution 1373, was a main concern for successive UN high commissioners for human rights. ${ }^{107}$ On October 21, 2002 the then UN high commissioner, Sergio Vieira de Mello in his meeting with members of the CTC, noted these concerns and reinforced the need for the CTC to have a human rights advisor, as well as put necessary information on the non-derogation of some rights on its website. ${ }^{108}$ Though the CTC did not as much as make any effort to implement these suggestions, ${ }^{109}$ other events that later followed did remedy the errors of resolution 1373. For example, in November 2002 Mexico was able to get the UN General Assembly to adopt resolution $57 / 219$, requiring countries to make sure that their domestic counterterrorism legislation was compatible with international law, especially human rights, protection of refugees, and international humanitarian law. ${ }^{110}$ It reemphasized the need for some non-derogable rights to be respected at all times, and where states default, they must comply with the requirements of international law. ${ }^{111}$ It also asked the UN Secretary-General to submit reports to the UN Commission on Human Rights (UNCHR), as well as the General Assembly on the implementation of the resolution. ${ }^{112}$

Subsequently, UNSC resolution 1456 of 20 January 2003 provided that, "states must ensure that any measure taken to combat terrorism comply with all their obligation under international law, in particular international human rights, refugee and humanitarian law". ${ }^{113}$ Further to this, the UNSC adopted resolution 1624 of 2005, which stated that counterterrorism and human rights are not only complementary, but that both are important aspects of counterterrorism measures, and all steps taken in line with its paragraph 1 , 2 , and 3 , should be in compliance with obligations relating to international human rights law, refugee law and humanitarian law. ${ }^{114}$ Also, the UN global counterterrorism strategy added that;

The promotion and protection of human rights for all and the rule of law is essential to all components of the strategy, recognizing that effective counterterrorism measures and promotion of human rights are not conflicting goals, but complementary and mutually

107 HRW, supra, n. 36, 4.

108 Ibid.

$109 \mathrm{lbid}$, at 5.

110 A/RES/57/219; W.S. Heinz and J. Arend, supra, n. 36, 11; HRW, supra, n. 36, 5.

111 HRW, supra, n. 36, 5 .

112 Ibid.

113 Ibid; W.S Heinz and J. Arend, supra, n. 36, 11.

114 G.A. Res 1624, U.N. Doc. A/RES/1624 (14 September 2005), quoted in J. Santana, supra, n 33, 677, 678. 
reinforcing". 115

It further reemphasizes the nexus between human rights and security, to the end that both human rights and rule of law must be at the centre of every domestic and international counterterrorism framework. ${ }^{116}$ The above positions have been reinforced by Adarkwah, who cites the position of the UNSC, which is that countries must ensure that their domestic counterterrorism responses match their obligations in international law. ${ }^{117}$ This has been interpreted to mean that domestic counterterrorism legislations must respect human rights. ${ }^{118}$ Speaking on the conflict between human rights and counterterrorism in West African countries, he re-echoes the position of the CTC, which is that, "most states have used comparatively broad definitions of terrorism in their definition. This may pose a significant problem when interpreting terrorist conduct in compliance with human rights obligations". ${ }^{119}$ According to the committee, most countries also lack proper accountability framework for human rights violations by security operatives. ${ }^{120}$ The meaning is that with accountability missing, abuse becomes commonplace. ${ }^{121}$

The implication of the above developments is that, notwithstanding the initial stance of resolution 1373, the UN Human rights system has come to recognise the futility in fighting terrorism, without incorporating human rights. As a matter of fact, it has been noted that safeguarding human rights in counterterrorism is more than just a legal prerequisite, but incidental to the overall success of the war against terror. ${ }^{122}$ As the UN SecretaryGeneral remarked before the CTC, "to pursue security at the expense of human rights, short-sighted, self-contradictory, and, in the long run, self-defeating". ${ }^{23}$ Though human rights and counterterrorism are not really cognates in term of origin, the fact that both, under the present circumstances, relates to the protection of the human society, imposes an obligation on member states of the UN to strive to strike a balance between the two in their domestic legislations.

115 UNHCHR, 'Human Rights Terrorism and Counter-Terrorism', (2008), Office of the United Nations High Commissioner for Human Rights, Fact Sheet No. 321 - 72.

$116 \mathrm{Ibid}$, at 21.

117 SC Res 1456, UN SCOR $58^{\text {th }}$ Sess. 4688mtg, UN. Doc. S/RES/1456 (2003), quoted in S.B. Adarkwah, supra, n. 34, 62.

118 S.B. Adarkwah, supra, n. 34, 62.

119 lbid.

$120 \mathrm{lbid}$.

$121 \mathrm{lbid}$, at 63.

122 HRW, supra, n. 36, 3.

$123 \mathrm{Ibid}$. 
This balance is important, for a number of reasons. To start with, respect for human rights in counterterrorism secures the same norms that the terrorists are trying to destroy and garners support for the state. ${ }^{124}$ This point has been noted by a former UN special rapporteur, Martin Scheinin who stated that;

Compliance with all human rights while countering terrorism represents a best practice because not only is this a legal obligation of states, but it is also an indispensable part of a successful medium - and long-term strategy to combat terrorism. ${ }^{125}$

This balance does not protect the terrorist, but ensures that states do not abuse their powers and become tyrannical. Under a balanced framework, suspected terrorists after been apprehended, can be detained as a preventive measure, and within a reasonable time brought before a court of competent jurisdiction, to ensure that they are accordingly convicted. This way, leaders with tyrannical dispositions will not be gifted with an opportunity of exploiting the law to punish their opponents. More so, achieving such balance will help to directly attack the issues that are at the root of terrorism.

In comparative terms, such a balanced system is already being developed in the United Kingdom (UK), a jurisdiction that has succeeded in gradually bringing human rights values into its fight against terror. Post-9/11 legislative development in the UK led to the enactment of the Anti-Terrorism, Crime, and Security Act (ATCSA) of 2001, which provided for a rather expansive counterterrorism framework, that directly infringed on human rights. ${ }^{126} \mathrm{~A}$ sore part of the ATCSA was the provision for 'indefinite detention without trial' of non-Britons, which was viewed not only as discriminatory but also a violation the UK Human Rights Act of $1998 .{ }^{127}$ Under the ATCSA, the UK Secretary of State for Home Affairs had the power of certifying whether a detainee, was a terror suspect or national security threat. ${ }^{128}$ The ATCSA was however repealed following the decision in A v. Secretary of State for the Home Department, ${ }^{129}$ where it was held that part 4 of the ATCSA was in violation of the European Convention for the Protection of Human Rights and Fundamental Freedoms. ${ }^{130}$

124 N. Mavronicola, supra, n. 102, 5.

$125 \mathrm{lbid}$.

126 C.A. Honeywood, 'Britain's Approach to Balancing Counterterrorism Laws with Human Rights', (2016, 9 (3), Journal of Strategic Security, 28 - 48 at 21.

127 Section 33, part 4, ATCSA, cited in C.A. Honeywood, supra, n. 125, 32.

128 HRW, supra, n.36, 20.

129 (2004) UKHL 56.

130 C. Marken, supra, n. 32, 2, 3. 
In the UK, pursuant to the Prevention of Terrorism Act, 2005 and Terrorism Act, 2006, a maximum number of twenty-eight (28) days is provided for the detention of a terrorism suspect, with the proviso that such order is to be granted by a High Court Judge. ${ }^{131}$ Overall, the current UK standard is commendable as it inches towards better human rights standards. The current renewable 90 days detention period under the Nigerian Act is not only draconian, it is importantly a perfect recipe for abuse of power, particularly as the article has established.

\section{The Way Forward}

The current brutality and high-handedness sublimated into Nigeria's counterterrorism law, is an expression of lack of regard for human rights norms. The assault on the right to dignity and personal liberty under Nigeria's counterterrorism framework, is beyond human standards. As Hornle and Kremnitzer has noted, "the right to have one's human dignity respected is a defensive and individual right". 132 Terrorist wreak havoc; the State must not also be found wreaking worse havoc, using the law as a cover. As a country continues in its democratic journey, it is imperative that all the essential components necessary for the sustenance of democratic values are in place. One of such is respect for the rule of law, under which fundamental human rights features as a major pillar. It has been rightly noted that when it comes to advancing democracy and human rights, rule of law is an important implement. ${ }^{133} \mathrm{~A}$ similar point has also been made by former UN Secretary-General, Kofi Annan who observed that the rule of law and human rights are two important ingredients for developing state capacity to combat terrorism. ${ }^{134}$

One inference that can be drawn is that the fact that the Act features a number of retrogressive provisions is a fallout of Nigeria's rigid and frenzied adherence to UNSC Resolution 1373. It is however important to state that accountability would have been take care of where the Act is worded, taking into consideration Nigeria's IHRL obligations. This obviously was the intention of the UN with the subsequent adoption of resolution 1624. Nigeria ought to have reviewed its counterterrorism legislation in this light and accordingly fallen in line. The 2013 amendment even though a job well-done, through its brilliant incorporation of the crime of terrorist financing, is still significantly insufficient 131 Ibid.

132 T. Hornle and M. Kremnitzer, 'Human Dignity as a Protected Interest in Criminal Law', (2011), 44 (1), Israel Law Review, $143-167$ at 148.

133 A.D. Bostan, 'The Right to a Fair Trial: Balancing Safety and Civil Liberties', (2004), 12 (1), Cardozo Journal of International and Comparative Law, $1-40$ at 1.

134 H.W. Gebreegziabher, 'The Right to Privacy in the Age of Surveillance to Counterterrorism in Ethiopia', (2018), 18, African Human Rights Law Journal, 392 - 412 at 398. 
by not incorporating the noble intentions of Resolution 1624 . This necessarily calls for a further review of the Act. To demonstrate its commitment to balancing the war on terror with its human rights obligations, the government must move towards bringing certain provisions of the Act into compliance with its IHRL obligations and current developments under the UN human rights system. Article 2 (2) of the ICCPR provides this obligation stating that;

Where not already provided for by existing legislative or other measures, each state party to the present covenant undertakes to take the necessary steps in accordance with its constitutional processes and with the provisions of the present covenant to adopt such legislative or other measures as may be necessary to give effect to the rights recognized in the present covenant. ${ }^{135}$

It is important to stress that the operative part of Article 2 (2) of the ICCPR are the clauses "where not already provided for by existing legislative or other measures," and "to adopt such legislative or other measures as may be necessary to give effect to the rights recognized in the present covenant". Nigeria acceded to the ICCPR on July 29 1993, is therefore under an obligation to give effect to the rights in the covenant in any existing legislative document such as the Terrorism Prevention (Amendment) Act 2013. To this end, there is an urgent need to review certain provisions of the Act that undermines the country's IHRL obligations.

Importantly, the provision for 'indefinite detention of terrorism suspects' under section 27 (1) and 28 (4) of the Act, is a provision earnestly in need of review. In amending this section, valuable lessons can also be drawn from the UK 28 days detention rule already alluded to above. The assault on the powers of the court in granting bail pending the completion of trial which the Act seeks to challenge, must also be reviewed as it violates the powers of the court to determine the liberty of persons at all times. The Nigerian government in its war on terror cannot always be a judge in its own cause; being the accuser as well as usurping the powers of the court. It cannot continue to wrestle with the court on who should, or should not be granted bail pending conclusion of trial. All of these clearly discredits the government's counterterrorism effort and deprives it of the needed citizen support. The government must know that human rights treaties are binding on countries that ratify them. Additionally, advancements in human rights regimes, subjects a government's treatment of its citizen to scrutiny and intervention by external parties. ${ }^{136}$ 135 ICCPR 1966.

136 W.M. Cole, 'Sovereignty Relinquished? Explaining Commitments to the International Human Rights Covenants 1966 - 1999', (2005), 70, American Sociological Review, 472 - 495 at 473. 
The current approach of unguardedly apprehending suspected enemies of the government on trumped up charges of terrorism and subsequently casting their rights into the bin, must be done away with. Such will not only continue to weaken the credibility of the government both home and abroad, it will inordinately continue to allow the main terrorist escape with their evil deeds. As long as those obnoxious provisions already discussed in this article, are left to remain as they are, the government's counterterrorism effort is likely to remain steeped in needless controversies and avoidable judicial reprimanding. Much responsibility is therefore placed on the shoulders of noble men of right and deep thinking to appreciate the interconnectedness between the human rights and counterterrorism, and do what is right devoid of the promises or perils of the moment. The pathway to development lies not in pursuing a direct closed answer to satisfy one side, but to understand the place of both in national governance, towards ensuring the right balance. It is important to alertly confront this together as those in government and those been governed.

\section{Conclusion}

This article has examined Nigeria's war on terror and how it violates the country's IHRL obligations in respect of the right to dignity and personal liberty. The article finds that the Terrorism (Prevention) (Amendment) Act 2013, accommodates sweeping provisions that do not take Nigeria's international human rights obligations into consideration. All of this may have been due to the pressure on the government, to realise UNSC resolution 1373 as manifestly as possible. The article therefore calls for a review of sections 27 (1) and 28 (4) of the Act, to reflect the good intentions of resolution 1624.

It is worth reaffirming that domestic counterterrorism does not exist in a vacuum. The fact that terror suspects are deemed as high network individuals, posing great risk to national security, does not provide a justifiable basis to sidestep established human rights norms. The erosion of human rights, is not only a gradual descent to tyranny, but most importantly a creeping erosion of humanity in any society. The need to provide a bulwark against the tyranny of men, was a major factor in the development of human rights treaties. It was the basis on which human rights was deemed a universal phenomenon, following which UN member states began to commit themselves accordingly. The obligations which later followed, being not decorative, were expected to be binding on states, to the end that they take domestic steps consistent with these obligations. The prime position of human rights cannot be substituted with the weaponization of the war on terror. In the event that 
human right is made to abdicate its position all in the name of counterterrorism, then the war on terror itself must be seen as an act of terror. 